\title{
The Problems and Countermeasures of College Students' Off-campus Internships
}

\author{
Zhenbo Bao ${ }^{1, a^{*}}$, Dengchao Jin ${ }^{1, b}$, Jinxing Peng ${ }^{1, c}$ and Xinyuan Liu ${ }^{1, d}$ \\ ${ }^{1}$ Engineering and Technology College, Tianjin Agricultural University, Tianjin, China, 300384 \\ a*zhenbobao@sohu.com, bjindengchao@163.com, \\ cpengjinxing@163.com, diuxinyuan@tjau.edu.cn
}

\begin{abstract}
Keywords: College students; Off-campus internships; Problems and countermeasures;
\end{abstract} Government and internship units

\begin{abstract}
College students' off-campus internship is an important way to improve professional skills and employability. It is an internal requirement to cultivate students' social responsibility, innovative spirit and practical ability, and improve their quality. There are some problems in college students' off-campus internships, such as the government's support for university students' internships support policies is insufficient, colleges and internship units do not have effective management mechanisms, the internship unit lacks incentives and security policies for internships, some intern students lack proper attitudes toward internships, and the lack of effective legal protection for university students during the internship period, which affect the effective development of internship activities and the quality of internships. Through the analysis of the problems existing in college students' off-campus internships, some guarantee measures to improve the quality of college students' off-campus internships, such as strengthening the support of government policies and legal systems, strengthening the university internship organization, strengthening the internship process management, strict evaluation of internship results, and improvement of practice safety precautions, etc. are put forward. Strengthening the quality of college students' off-campus internships is of great significance to safeguarding the legitimate rights and interests of college students and improving the quality of personnel training.
\end{abstract}

\section{Introduction}

The off-campus internship of college students is the basic link and core part of education and teaching. It is an important way to strengthen theoretical connection with practice, verify what is known and learn, and improve employment ability. The off-campus internship is an internal requirement to cultivate and enhance students' sense of social responsibility, innovative spirit and practical ability. Strengthening the quality of college students' off-campus internships is of great significance for safeguarding the legitimate rights and interests of college students, and improving the quality of talents training [1,2]. There are some problems in the off-campus internships of college students, which affect the effective development of internship activities for college students. It is of great significance to improve the quality of college students' off-campus internships through analyzing the problems of off-campus internships and taking corresponding improvement measures.

\section{The Problems Existing in College Students' Off-campus Internships}

The quality of college students' off-campus internships greatly affects the university graduates' views on society and further influences college students' employment and entrepreneurship. Therefore, the government, universities, internship institutions, and college students must pay high attention to the students' off-campus internships. But, in the process of organizing college students to conduct off-campus internship activities, and through the review of relevant documents and materials, there are some problems in the off-campus internship activities. The problems in the off-campus internships of college students, such as insufficient policy support, non-strict internship organization and process management, non-standard internship assessment, and hidden dangers of internship safety, all affect the 
effective development of college students' internship activities [3, 4]. The problems existing in college students' off-campus internships are summarized and shown in Table 1.

Table 1 The problems existing in college students' off-campus internships

\begin{tabular}{|c|c|}
\hline Problems & Detalled des \\
\hline $\begin{array}{l}\text { The government's } \\
\text { support for college } \\
\text { students' internship } \\
\text { policy is } \\
\text { insufficient. }\end{array}$ & $\begin{array}{l}\text { The government needs to formulate a policy system that inspi } \\
\text { arrange interns, and improve a set of internship systems that at } \\
\text { the development of education in China and the develop } \\
\text { economy. There is a need to establish a legal system for u } \\
\text { which clearly defines the identity of university interns and prc } \\
\text { personal safety. }\end{array}$ \\
\hline $\begin{array}{l}\text { Universities and } \\
\text { internship units } \\
\text { have not formed } \\
\text { an effective } \\
\text { management } \\
\text { mechanism. }\end{array}$ & $\begin{array}{l}\text { leges and universities rarely organize college st } \\
\text { ning, and some internships are not relevant to } \\
\text { versities lack follow-up on students' internship } \\
\text { e perfect information collection and practice sur } \\
\text { cess. }\end{array}$ \\
\hline $\begin{array}{l}\text { Insufficient } \\
\text { incentives } \\
\text { guarantees and } \\
\text { internships. }\end{array}$ & $\begin{array}{l}\text { iship } \\
\text { lents } \\
\text { The } \\
\text { The } \\
\text { re to }\end{array}$ \\
\hline $\begin{array}{lr}\text { e } & \text { internship } \\
\text { ents } & \text { lack } \\
\text { ect } & \text { attitude } \\
\text { ard internships. }\end{array}$ & onsibility for comple \\
\hline $\begin{array}{l}\text { College students } \\
\text { are vulnerable } \\
\text { groups in their } \\
\text { internships. }\end{array}$ & $\begin{array}{l}\text { lents must complete the school's prescribed internships. However, the } \\
\text { nship unit does not sign a formal labor contract with the intern students. } \\
\text { en the internship issues such as work-related injuries, labor remuneration, } \\
\text { unfair working hours occur, the rights of internship students cannot be } \\
\text { anteed. The student's internship remuneration is not high, generally lower } \\
\text { the local minimum wage standard. }\end{array}$ \\
\hline
\end{tabular}

\section{Measures to Improve College Students' Off-campus Internships}

The effectiveness of off-campus internship is closely related to the government, universities, internship units and students themselves. The quality of college students' off-campus internship can be improved from the aspects of strengthening the government's policy support and legal system formulation, standardizing university internship organization, rigorous internship process management, standardizing internship results assessment, and safeguarding internship safety precautions[5, 6].

The Government Strengthens the Support to Off-campus Internship Work. The government plays a leading role in the establishment of internship encouragement policy and the establishment of relevant legal systems. It plays a positive role in urging universities and internship organizations to actively organize college students' internships. The government should strengthen the government's support for the internship of college students from the establishment of provincial college internship service centers, the improvement of laws and regulations concerning off-campus internship, the improvement of tax incentives for internships, and the improvement of policy support for university internship organizations $[3,5]$. The countermeasures for the government to strengthen the support for college students' internships are shown in Table 2. 
Table 2 The countermeasures for the government to strengthen the support for college students' internships

\begin{tabular}{|c|c|}
\hline Countermeasures & \\
\hline $\begin{array}{l}\text { Establish provincial } \\
\text { student internship } \\
\text { service center. }\end{array}$ & $\begin{array}{l}\text { The provincial student internship service center collects relevant information } \\
\text { of enterprise units, university interns, and universities in the province, and } \\
\text { provides each party with its own public information. The company has } \\
\text { purposeful and planned internship positions for university students to make } \\
\text { inquiries and applications. The internship effect evaluation system was } \\
\text { introduced, and college students evaluated the internship position and } \\
\text { internship rights provided by the internship unit. The enterprise unit } \\
\text { summarizes the student's internship and internship results. }\end{array}$ \\
\hline $\begin{array}{l}\text { Improving laws and } \\
\text { regulations related } \\
\text { to college students' } \\
\text { internships. }\end{array}$ & $\begin{array}{l}\text { ternships, } \\
\text { internship } \\
\text { onditions, } \\
\text { legitimate }\end{array}$ \\
\hline $\begin{array}{l}\text { Improve tax } \\
\text { incentives for } \\
\text { relevant internship } \\
\text { units. }\end{array}$ & $\begin{array}{l}\text { the corresponding laws and regulations and } \\
\text { rt for the internship units that support college } \\
\text { ship units that receive college students to carry } \\
\text { hile those that do not support college students' } \\
\text { ourage internship institutions and colleges and } \\
\text { lop internship plans, internship process } \\
\text { ssessment. }\end{array}$ \\
\hline $\begin{array}{l}\text { Improve supporting } \\
\text { policies } \\
\text { internship } \\
\text { organizations } \\
\text { universities. }\end{array}$ & $\begin{array}{l}\text { Colleges and universities should strengthen the service and management of } \\
\text { undergraduate internships and establish school-level and college-level } \\
\text { undergraduate internship service centers to establish information sharing } \\
\text { platforms for internships. Establish an evaluation system for undergraduates } \\
\text { and internship organizations for college internship organizations. Based on the } \\
\text { evaluation results, increase or decrease financial allocations to colleges and } \\
\text { universities. }\end{array}$ \\
\hline
\end{tabular}

Strengthen internship process management. Schools should effectively strengthen the construction of internships, formulate specific management methods and safety management regulations for student internships, and establish institutional documents such as emergency plans for emergency and student safety. Schools should strengthen the supervision of the whole process of the internship and conduct dynamic management of internship. Schools should regulate the internship agreement, internship student requirements, and internship instructors, etc.

Enhance the Examination Work for Off-campus Internship Work. School should establish an apprenticeship assessment system to clarify the appraisal standards for off-campus internship. The assessment results should be included in the student's academic performance. Students who violate the rules and regulations of internships shall be criticized and educated. If the violations are serious, the school shall impose disciplinary sanctions on them; if property losses are caused to the intern, they shall be compensated according to law. The school keeps the internship materials such as internship agreement, internship plan, internship report, internship assessment result, internship log and internship summary $[5,7]$.

Strengthen Internship Safety Precautions. The internship organization should implement the relevant safety production standards, improve the safety production rules and operating procedures, and formulate emergency rescue plans for production safety accidents. The internship unit and the school conduct training on safety production education, safety protection, and operation procedures for students' internships to ensure personal safety during student internships. Schools and internship units should insure student internship liability insurance for interns according to relevant state regulations. If 
the student is personally injured during the internship and falls within the scope of the internship liability insurance coverage, the insurer will pay the insurance contract according to the indemnity standard; if it is not covered by the insurance coverage, the intern, the school and the student shall bear the responsibility according to the internship agreement [7].

\section{Summary}

College student practice is a systematic project. The government must establish a college student internship service center and a student internship comprehensive service information platform to achieve the docking of internship positions and internship students. The government should inspire corporate units to accept university interns through tax incentives and internship appraisal. The government should urge colleges and universities to pay more attention to internships by controlling financial allocations. The government should introduce laws and regulations concerning undergraduate internships and provided certain legal protection for undergraduate internships. The internship unit needs to actively cooperate with the university and jointly manage the internship process. Undergraduates themselves have a good practice attitude and comply with the relevant provisions of off-campus practice. In short, through the joint efforts of governments, enterprises, universities, and students, can effectively improve the effectiveness of students' off-campus internship [7, 8].

\section{Acknowledgements}

This work was sponsored by Tianjin Agricultural University Teachers Education Reform and Innovation to Guide the Development of the Project No. 20170904 and Tianjin Agricultural University off-campus internship base key construction project No. 2018-19.

\section{References}

[1] H.L.Wang: Journal of Chifeng University (Natural Science Edition), Vol. 32(2016)No.12, pp. 239-240.

[2] L. Han: CHTNESE UNTVERSTTY TECHNOLOGY TRANSFER, (2017) No.1, p.121-123.

[3] Y.X.Ma: JOURNAL OF JIAMUSI VOVATIONAL INSTITUTE (2016) No.4, pp. 248-249.

[4] X.W. Li: JOURNAL OF LONGYAN UNIVERSITY, Vol. 34 (2016) No.1, p.84-87.

[5] L. Zhang, X.F.Wang: CHINA HIGER EDUCATION RESEARCH, (2011) No.8, pp.57-59.

[6] K.L. Zhang: Theory and Practice of Education, Vol. 31 (2017) No.12, p.21-23.

[7] G.H. Huang: JOURNAL OF MINNAN NORMAL UNIVERSITY, Vol. 30 (2016) No.3, p.150-152.

[8] C.L.Ma: ABILITY AND WISDOM, (2017) No.21, pp.33. 